\title{
THE IMPACT OF FISCAL POLICY ON ECONOMIC GROWTH DEPENDING ON INSTITUTIONAL CONDITIONS
}

\author{
[Vliv fiskální politiky na ekonomický růst v závislosti na institucionálních \\ podmínkách]
}

\author{
Rudolf Macek $^{1}$, Jan Jankü ${ }^{2}$ \\ ${ }^{1}$ VŠB - Technical University of Ostrava, Economic Faculty, Sokolská 33, 70121 Ostrava \\ Email:rudolf.macek@vsb.cz \\ ${ }^{2} V \check{S} B$ - Technical University of Ostrava, Economic Faculty, Sokolská 33, 70121 Ostrava \\ Email:jan.janku@vsb.cz
}

\begin{abstract}
This paper examines the impact of fiscal policy on economic growth depending on the institutional conditions in the OECD countries over the time period 2000-2012. The analysis is based on the methods and tests of panel regression. From the analysis results it is evident that in the case of government spending there is (1) positive impact on economic growth in the countries with lower fiscal transparency; (2) negative impact in countries with higher fiscal transparency. In less developed countries there is higher proportion of pro-growth spending within total government spending. On the other hand in more developed countries the Wagner law becomes valid with the existence of welfare costs. In the case of taxation impact on economic growth it is visible that (3) the negative impact of taxation is more harmful for economic growth in the countries with worse institutional conditions. The explanation of this result can be linked to different fiscal transparency and different economic level.
\end{abstract}

Keywords: economic growth, fiscal policy, government spending, institutional factors, OECD, taxation.

JEL classification: $\mathrm{H} 20$, O40, E62, O17

Doručeno redakci: 6.5.2015; Recenzováno: 21.5.2015; 9.6.2015; Schváleno k publikování: 23.9.2015

\section{Introduction}

In general, fiscal policy can be considered as one of the most important economic policies of chosen economic-policy makers. The significance of fiscal policy is especially perceived in connection with basic functions of this policy, such as allocation, stabilization and redistribution. However, it is necessary to realize that fiscal policy must be also perceived as the tool of economic growth. Fiscal policy is usually represented by the level and structure of government spending on the one hand and by the level of individual taxes, resp. tax mix on the other hand.

It is also necessary to realize that the issue of the mutual interaction of fiscal policy and economic growth belongs among important topics. Main reasons do not derive only from the fact that fiscal policy has the potential to influence the long-term economic growth, but they also lie in the further mentioned facts. Current, modern and globalized society is characteristic by the necessity of the redistribution processes existence, which are usually represented by the level of government spending. The existence of government spending is conditioned by the necessity of its financing, where the taxes can be considered as one of the most important revenues of the public budgets. However, there does not exist the unified opinion among the economists and politicians about the way and range of taxation, or necessary amount of government spending financing a wide spectrum of activities. 
Many developed countries integrated in the OECD are currently affected by the evident public finance crisis, too. Therefore the individual countries are exposed to an increased supervision from the financial markets. Individual political authorities have to consolidate public budgets by the decrease of government spending level on the one hand and by the increase of tax revenues on the other hand.

Taxation or government spending impact on economic growth is the topic of many works, see e.g. Kotlán, Machová and Janíčková (2011) or Macek (2014). However, available studies usually work with the OECD countries as a whole and do not consider the different institutional conditions. Therefore, the aim of this paper is to examine the impact of fiscal policy on economic growth depending on the institutional conditions in the OECD countries over the time period 2000-2012. The methods of panel regression and OLS method are used in the analysis.

\section{The impact of taxation and government spending on economic growth within institutional conditions}

Fiscal policy, as a part of state's economic policy is characteristic by its basic aims among which definitely belongs the stimulation of economic growth. This policy is usually executed by changing the amount or structure of government spending and taxes. Gemmel, Kneller and Sanz (2011) state that the impact of fiscal variables on economic growth is ambiguous and depends on their nature. Concretely, the impact of distortion and non-distortion taxes, or productive and unproductive spending on economic growth. Distortion taxes and unproductive government spending decrease economic growth. Productive government spending will have a pro-growth effect only if they are financed by non-distortion taxes.

\section{Institutional conditions}

It is necessary to realize that traditional neoclassical growth models (Solow, 1956; Swan, 1956) explain the differences in income per resident by the accumulation of production factors. In these models there are then the differences among countries caused by exogenous parameters (e.g. total factor productivity). Romer (1986) or Lucas (1988) make technological progress and product growth in a stable state endogenous. They determine only mechanisms which explain in what way it leads to the growth (e.g. innovation, education, capital accumulation), but do not explain the reason why some countries are able to apply these growth incentives and others are not. North and Thomas (1973) state that these factors are not the sources of growth but they are the immediate causes of growth. Also the fundamental differences in economic growth are caused by the differences in institutions.

This paper is dealing with the influence of government spending and taxation on economic growth in the countries with different structure of institutions. Concretely, institutions connected with the quality of public administration, regulation quality, transparency, trustworthiness of fiscal policy or corruption level are important for this study.

Olson (1982) empirically confirmed that good government institutions are an important determinant of economic growth. According to the International Monetary Fund, IMF (2007), higher fiscal transparency (i.e. implementation of a more credible and predictable fiscal policy) leads to an easier access to the capital markets and also helps in preventing of economic crisis existence. Folscher, Krafchik and Shapiro (2000) claim that the institutalization of transparency in economic practice creates a demand for concrete types of government system. They consider these government system types as the key factor of 
anticorruption policy. Namely it is independence, effective audit systems, the implementation of the responsibility principle, the existence of the information system which provides accurate information. Djankov et al. (2003) point out that more transparent government enables the economies to solve economic failures with lower social costs. Brixi and Irvin (2004) mention that fiscal institutions - rules, practices, organizations of fiscal policy are the main determinants of quality decision making about the fiscal support of the economy.

\section{Taxation and its impact on economic growth}

Growth theories can be in current macroeconomics considered as fundamental elements enabling to explain the impact of key variables on economic growth. It is necessary to realize that taxation influences economic growth solely through its impact on individual growth variables, which are capital accumulation and investment, or human capital (Macek, 2014; Kotlán, Machová and Janíčková, 2011).

Dwenger (2009) states that corporate taxation lowers the return of invested capital and influences also the capital structure or the company's age. Dreßler (2012) claims that taxation determines the foreign direct investment (FDI) inflow and plays a significant role in the investor's decision making about the investment localization. It is necessary to realize that entrepreneur's investment decisions can be influenced by the labour taxation, too. Alesina et al. (1999) state that the main reason for this fact is that the growth of labour tax rate leads to the employees' effort to get salary increase at a same level (before the taxation). By this, pressure is created on companies to lower their profits, and consequently their investment, too.

A positive relations between investments into human capital and long-term economic growth were confirmed by many studies; see e.g. Teixeira and Fortuna (2003) or Jones and Manuelli (2001). Lin (2001) confirms that a positive dependency can exist between economic growth and taxation if revenues from taxes are used only for human capital accumulation.

Several studies deal with the issue of taxation impact on economic growth in the case of developed or less developed countries or in the conditions of openness see e.g. Palomba (2004). However, none of the available studies evaluates the impact of taxation depending on institutional conditions.

\section{Government spending and its impact on economic growth}

Within the impact of government spending on economic growth it is necessary to realize that their impact depends on the fact if productive or unproductive government spending prevail (Kneller, Bleaney a Gemmell, 1999). Barro and Sala-i-Martin (2004) or Kneller, Bleaney and Gemmell (1999) among productive government spending incorporate e.g. investment into education and human capital, spending on defense, infrastructure or healthcare. Unproductive government spending are mainly social security contributions.

Further it is necessary to mention the work of Tanzi and Zee (1997) explaining "Wagner's law". Wagner's law states that economic growth can lead to increased demand for government services and "welfare spending". According to this law, in fully developed countries government spending raise from three main reasons. (1) socio-political: e.g. social and health insurance; (2) economic: thanks to the science and technology the increased engagement of the state in technological projects is required; (3) historical: growth of 
government spending lead in the end to the government debt increase. Therefore, if these spending suppress investments or government spending into education, then the impact of total government spending cannot be pro-growth.

But only a very few studies research the productivity of government spending in the case of different institutional conditions. E.g. Butkiewicz and Yanikkaya (2011) evaluate the influence of government spending on economic growth, where they study how the government effectiveness influences the efficiency of government spending. They do not classify government spending into productive and unproductive a priori, but they divide countries into two groups according to the effectiveness/ineffectiveness of government institutions. The first finding is that government consumption has a negative growth effect for certain groups of countries. The negative pro-growth effect of this spending can be seen especially in developing countries with inefficient governments, whereas in developing countries with efficient governments this impulse is insignificant. Second finding is that capital spending have a positive pro-growth effect in developing countries with inefficient governments and also in developing countries as a whole. Generally, these two results mean that government efficiency (efficiency of government institutions) is an important determinant of the economic growth in developing countries.

\section{Empirical analysis: Methodology, data and results}

In accordance with Barro and Sala-i-Martin (2004) approach, a homogenous group of countries will be analysed. Homogenous group of countries can be understood as the group of economies with similar production functions, institutional parameters etc. This approach is also kept in the analysis executed in this paper, where membership of a country in OECD is the basic homogeneity criterion. However, in connection with the aim of the article, this group of countries will be divided into two partial categories, where relatively more homogenous countries are grouped together $\left(\mathrm{OECD}_{19}\right.$ : Australia, Austria, Belgium, Canada, Denmark, Finland, France, Germany, Iceland, Ireland, Luxembourg, Netherlands, New Zealand, Norway, Spain, Switzerland, Sweden, United Kingdom, USA; OECD ${ }_{15}$ : Czech Republic, Estonia, Greece, Hungary, Chile, Israel, Italy, Japan, Korea, Mexico, Poland, Portugal, Slovenia, Slovakia, Turkey). This separation is based on institutional conditions, where the main criterion is the transparency of fiscal policy. ${ }^{1}$ This definition of institutional characteristics is very close to the world indicators of governance - Worldwide Governance Indicators (WGI). These indicators compare the efficiency of the government sector based on the long-term research program of World Bank. They represent six main dimensions of governance: voice and accountability; political stability and absence of violence; government effectiveness; regulatory quality; rule of law and control of corruption (Kaufmann, Kraay and Mastruzzi, 2010).

The partial index "government effectiveness" is the most appropriate sub-index for our analysis. This indicator reflects the perception of public services quality; the level of public services independence on political pressure; the quality of formulating and executing economic policy and the trustworthiness of individual governments.

\footnotetext{
${ }^{1}$ Kopits and Craig (1998, p. 1) define fiscal transparency as the "openness toward the public at large about government structure and functions, fiscal policy intentions, public sector accounts, and projections. It involves ready access to reliable, comprehensive, timely, understandable, and internationally comparable information on government activities - whether undertaken inside or outside the government sector - so that the electorate and financial markets can accurately assess the government's financial position and the true costs and benefits of government activities, including their present and future economic and social implications.“
} 
The percentile evaluation of individual countries is ranked into six categories and the highest evaluation corresponds to the 90-100 percentiles. Those countries, within the index of "government effectiveness" can be considered as highly transparent in implementation of economic policy. The criterion for the countries separation according to this characteristic can be the fact that individual country is placed at least once in the category "highly transparent" during the whole period 2000-2012. ${ }^{2}$

The econometric analysis derives from the widened neo-classical model of Mankiw, Romer and Weil (1992). In respect with this study, individual variables of the analyzed model can be written as: GDP - gross domestic product growth per resident expressed by the amount of real GDP per capita in purchasing power parity in USD (dependent variable); ${ }^{3}$ GDP(Y2000) initial value of gross domestic product per resident; RINV - capital accumulation approximated by the indicator of proportion of real investment to GDP, expressed in purchasing power parity per one resident; HUM - human capital which is approximated by the proportion of people with a minimum of secondary education onto total manpower; ${ }^{4}$ GOV - total government spending as a \% of GDP; TAX - taxation approximated by tax quota (TQ), where category [1100] represents personal income taxes; [1200] corporate income taxes; [2000] social security contributions; [4000] property taxes; [5110] value added tax; [5120] other taxes on consumption.

The aforementioned description of individual variables included in the model can be written into a mathematical formula shown in equation (1).

$$
\begin{aligned}
& G D P_{i t}=\alpha+\hat{\beta}_{1} G D P_{i, 2000}+\hat{\beta}_{2} R I N V_{i t}+\hat{\beta}_{3} H U M_{i t}+\hat{\beta}_{4} G O V_{i t}-\hat{\beta}_{5} T A X_{i t}+ \\
& +\hat{u}_{i t} \text {. } \\
& \mathrm{i}=1 \ldots 15(19) ; \mathrm{t}=2000 \ldots 2012
\end{aligned}
$$

The data about the amount of GDP per resident in purchasing power parity and government spending were acquired from the OECD National Accounts Statistics database. The information about the proportion of investment to GDP is from the Penn World Table database (Penn World Table - database 1950 - 2011). Human capital is acquired from OECD Education at Glance and information about tax quota come from the OECD Tax Statistics.

From the methodological point of view methods and tests of static panel regression are used. Within the panel regression, the pool data model was used. The main econometric program is E-views, version (7), which enabled us to realize all common econometric tests, according to e.g. Wooldrige (2009). Generally, there are three basic models for estimating parameters in econometric regression models, where Wooldrige (2009) states that when creating

\footnotetext{
${ }^{2}$ The index fluctuates in time very rarely, so if the country places in this evaluation only once in the highest category, it stays there in the other years as well. Exceptions in this matter are France, Spain and Ireland, which are below this level in certain years.

${ }^{3}$ Barro and Sala-i-Martin (2004) work with the average data for 10 or 5 years in their empirical analysis of economic growth and conditional convergence. In our analysis the data are based one year periodicity because this analysis will be later expanded through World Tax Index as main approximator of taxation which is available only from year 2000. Because authors of the article will try to compare impact of taxation approximated by tax quota and World Tax Index in $\mathrm{OECD}_{19}$ and $\mathrm{OECD}_{15}$ it is necessary to work with same time interval. Also current works which deal with the issue of taxation impact on economic growth work with the one year periodicity data, see e. g. Kotlán, Machová and Janíčková (2011), Kotlán and Machová (2012), Macek (2014).

${ }^{4}$ Within the international classification of education levels ISCED, it is level ISCED3, ISCED4 and ISCED5.
} 
econometric regression models, the method of least squares (OLS) is used. This method was also used in the case of relevant analysis of Mankiw, Romer and Weil (1992). ${ }^{5}$

Before the panel regression evaluating the impact of taxation and government spending on economic growth was executed, it was necessary to test the stationarity of time series. There was tested the hypothesis of existence of single root. Stochastic instability was found with GDP, GOV and TQ [2000] and therefore these variables were transformed to the first difference, which were already stationary. ${ }^{6}$

Wooldridge (2009) states that in the case of utilizing the macroeconomic data in the situation where the cross-sectional units are countries, the model with fixed effects seems to be more appropriate. Appropriateness of utilizing fixed effects was tested by Hausman test. Therefore the estimations of models were made by OLS method with using cross section fixed effects. All models were also estimated by the White Period method which eliminates the possible occurrence of heteroskedasticity and autocorrelation, where it utilizes asymptotic covariance matrices without changing the estimation method. Due to this, it is possible to consider the estimates of regression coefficients, $t$-statistics and standard deviations as credible.

Table 1: The impact of fiscal policy on economic growth in the countries with lower fiscal transparency (2000-2012)

\begin{tabular}{|c|c|c|c|}
\hline \multirow{2}{*}{ VARIABLE } & \multirow{2}{*}{$\begin{array}{l}\text { Coefficient } \\
\text { (t-Statistic) }\end{array}$} & \multicolumn{2}{|c|}{ Economic verification } \\
\hline & & Theory & Empiricism \\
\hline GDP(Y2000) & $-301,32(-1,01)$ & - & - \\
\hline RINV & $103,02(4,80)^{* * *}$ & + & + \\
\hline HUM & $26,69(0,19)$ & + & + \\
\hline D(GOV(-1)) & $346,48(3,25)^{* * *}$ & $+/-$ & + \\
\hline TQ1100(-1) & $-103,46(-2,21)^{* *}$ & - & - \\
\hline TQ1200(-1) & $-229,80(-1,94) * *$ & - & - \\
\hline D(TQ2000) & $-389,28(-2,56)^{* * *}$ & - & - \\
\hline TQ4000 & $-398,10(-0,28)$ & - & - \\
\hline TQ5110 & $35,87(0,24)$ & - & + \\
\hline Adjusted $\mathbf{R}^{2}$ & 0,51 & & \\
\hline F-statistics & $11,21 * * *$ & & \\
\hline
\end{tabular}

Table 1 represents the results of the econometric analysis of the fiscal policy impact on economic growth in the countries with lower fiscal transparency. It is evident that the model as a whole is a statistically significant at a $1 \%$ significance level with the coefficient of determination at $51 \%$.

The impact of initial value of gross domestic product per resident is in harmony with the results of Makiw, Romer and Weil (1992), but this variable is statistically insignificant. Therefore it is not necessary to pay attention to this variable. Also current literature dealing

\footnotetext{
${ }^{5}$ This type of panel regression can be characteristics by the existence of endogeneity among individual variables. The endogeneity problem usually arises with using dynamic panel regression model. In this case it is necessary to use special differenced form of GMM with instrumental variables, so called Arellano-Bond estimator. Using dynamic panel regression with GMM method and instrumental variables will be the next step of our analysis. With using Arellano-Bond estimator and Sargan test (J-statistics) the endogenity problem will be eliminated.

${ }^{6}$ Using first differences do not change the interpretation of individual regression coefficients. If $Y_{t}=\alpha+$ $\beta X_{t} \rightarrow Y_{t-1}=\alpha+\beta X_{t-1}$, where $Y$ depends on $X$ in time $t$ and this fact is also valid in time $t$ - 1 . And if we subtract these equation we get $\Delta Y_{t}=\beta \Delta X_{t}$.
} 
with the impact of taxation on economic growth does not work with this variable, see e. g. Kotlán and Machová (2012) or Kotlán, Machová and Janíčková (2011).

Capital accumulation is statistically significant at a $1 \%$ significance level, where the assumed positive relation with economic growth was confirmed. This fact can be connected with conclusions of basic neoclassical growth model. Rise of capital accumulation represented by increased savings or investment activity is the basic source of economic growth up to the achievement of steady state.

The results of human capital impact are in accordance with theoretical assumptions, but this variable is not statistically significant. Despite this fact, it was kept in the model as a basic growth "controlled" variable.

In the case of government spending it is evident that this variable is lagging in the model by one period with statistical significance at a $1 \%$ significance level. It is necessary to mention that the change of government spending structure or level as one of basic economic-political decisions carried out by economic-political authorities is connected with time lag. Therefore, the empirical significance of government spending lag can be considered as justifiable. The analysis results show that government spending increases economic growth with one year lag and the variable is statistically significant at a $1 \%$ significance level. Also, it is evident that personal and corporate taxes lower economic growth with one year lag. This result can be considered as logical since personal and corporate income taxes can be classified as the most distortion taxes. Their change is connected to the time period during which the economic subjects are adjusting to the situation. Due to this, it is evident that the influence or the impact of income taxes can be lagging and also empirically quantifiable. Without the lag the variables were statistically insignificant. When it comes to the social security contribution, property taxes and value added taxes lagging values were statistically insignificant and therefore the values were kept in the model without the lag.

Personal income taxes are statistically significant at a $5 \%$ significance level. From the negative relation with economic growth can be assumed that this type of taxation unfavorably impacts the welfare and living standard of working individuals.

Corporate taxation is statistically significant at a $5 \%$ of significance level. It is possible to state, that this type of taxation lowers the return of capital, inflow of FDI or investment into human capital. Thanks to this its influence on economic growth is negative.

Social security contributions are statistically significant at a $1 \%$ significance level and also in this case the assumed negative relation with economic growth was confirmed.

It was not possible to estimate the individual impact of value added taxes and other consumption taxes because they were mutually correlated. Due to this and in accordance with econometric practice one category, concretely other consumption taxes, was excluded. From the table it is evident that property taxes and value added taxes are not statistically significant and therefore it is not necessary to deal with their impact on economic growth. 
Table 2: The impact of fiscal policy on economic growth in the countries with higher fiscal transparency (2000-2012)

\begin{tabular}{|c|c|c|c|}
\hline \multirow{2}{*}{ VARIABLE } & \multirow{2}{*}{$\begin{array}{c}\text { Coefficient } \\
\text { (t-Statistic) }\end{array}$} & Theory & Empiricism \\
\cline { 3 - 4 } & $-281,31(-0,45)$ & - & - \\
\hline GDP(Y2000) & $73,73(1,88)^{* *}$ & + & + \\
\hline RINV & $25,58(0,54)$ & + & + \\
\hline DUM & $-165,30(-2,23)^{* * *}$ & $+/-$ & - \\
\hline TQ1100(-1) & $66,67(0,89)$ & - & + \\
\hline TQ1200(-1) & $-227,54(-1,93)^{* *}$ & - & - \\
\hline D(TQ2000) & $-326,37(-1,43)^{*}$ & - & + \\
\hline TQ4000 & $353,23\left((1,90)^{* *}\right.$ & - & + \\
\hline TQ5110 & $75,17(0,27)$ & - & \\
\hline \multicolumn{2}{|c|}{0,39} & \\
\hline Adjusted R & $3,07 * * *$ \\
F-statistics & Note: *, **, *** represent the significance level at $10 \%, 5 \%$ and $1 \%$. \\
Source: own computation &
\end{tabular}

The results of the econometric analysis of the fiscal policy impact on economic growth in the countries with higher fiscal transparency are shown in table 2 . It is evident, that the model as a whole is again statistically significant at a $1 \%$ significance level with the coefficient of determination at $39 \%$.

The initial value of gross domestic product per resident is again statistically insignificant and it is also in harmony of Mankiw, Romer and Weil (1992) results.

Capital accumulation is statistically significant at a $5 \%$ significance level, where again the assumed positive relation with economic growth was confirmed. This result can be explained the same way as it was done in the previous model.

The impact of human capital on economic growth is also positive. This variable is not statistically significant and it was again kept in the model as a basic growth "controlled" variable.

It is evident that, similarly as in the aforementioned model, government spending, personal income taxes and corporate taxes are lagging by one period. Government spending is again statistically significant at a $1 \%$ significance level, however in this case the impact on economic growth is negative.

In the case of personal income taxes the negative relation with economic growth was not confirmed, however this variable is not statistically significant. Corporate taxes are, similarly as in the first analyzed model, lagging by one period. Corporate taxation is statistically significant at a $5 \%$ significance level and the relationship with economic growth is negative.

Social security contributions are statistically significant at a $10 \%$ significance level. Also in this case the negative relation with economic growth was confirmed.

Property taxes are statistically significant at a $5 \%$ significance level; however the assumed negative relation with economic growth was not confirmed. Tosun and Abizadeh (2005) state that an increasing ratio of property taxes has a positive impact on economic growth. Property taxes have, within the total tax burden of OECD countries measured by tax quota, the lowest 
percentage; however their percentage is within the researched period slowly growing. Due to this the positive relation of property taxes and economic growth can be considered as justifiable.

Value added tax is not statistically significant and therefore it is not necessary to pay attention to the impact of this tax on economic growth.

\section{Discussion}

At first it is necessary to realize, that the group of countries with lower transparency of public policies $\left(\mathrm{OECD}_{15}\right)$ can be to a certain level similar to less developed countries within OECD. Similarly, the group of countries with higher transparency of public policies $\left(\mathrm{OECD}_{19}\right)$ represents only the most developed countries of the whole OECD. ${ }^{7}$ This facts must be realized when we want to interpret the results of empirical analysis.

In countries with "bad" institutional conditions capital accumulation and human capital have relatively higher positive impact on economic growth than in countries with "good" conditions. In this case, the conclusion can be following. The countries in the first group are economically less developed, and they have less capital stock per resident available. Therefore (due to the decreasing marginal productivity of capital) the unitary accumulation of human and physical capital have a higher positive impact on economic growth. The countries are simply further from the steady state and therefore it comes to conditional convergence.

Government spending positively affect economic growth in the countries with lower fiscal transparency and in the case of countries with higher fiscal transparency the impact is opposite. It is necessary to consider two basic hypotheses here.

The first one derives from the fact that in less developed countries probably the investment into infrastructure prevails. According to the aforementioned studies investment into infrastructure have the pro-growth effect. On the contrary, in more developed countries probably the welfare expenditures prevail which have a negative impact on economic growth. Therefore it can be stated that Wagner's law is valid in the case of more developed countries. However to confirm this hypothesis the future analysis of authors must divide total government spending according to the function classification of government spending (COFOG). This enables us to strictly identify which effect of government spending prevails (productive or unproductive), because the impact of partial productive government spending might be negative and impact of unproductive spending positive (Drobiszová, 2013; Machová, 2013).

The second hypothesis lies in dividing the countries according to the fiscal transparency level. It can be assumed that countries with higher fiscal transparency can spend the public sources more effectively, in accordance with the needs of the economic development and growth. But in case of our analysis the empirical results show, that government spending is pro-growth in countries with lower fiscal transparency. In the case of countries with higher fiscal transparency is the results opposite. Apart from the reason mentioned in the previous section

\footnotetext{
${ }^{7}$ Since growing economic level is a basic requirement for the quality increase of institutional environment (and on the contrary the quality of institutional environment is one of the most important determinants of economic growth), then the institutional separation of countries to two groups will reflect also their economic development. Therefore, it can be assumed that the less developed countries will be the countries with worse institutional environment, too.
} 
also the institutional reason can be found. In countries with worse institutional conditions (in this case with worse transparency of public policies) public expenditures can be excessively spent on infrastructure investments. These investments provide much wider space for possible corruption behavior and for a non-transparent increase of the budget above the level which is shown by government spending in social area.

The differences of taxation impact on economic growth are explicable from the view of different fiscal transparency and also from the view of different economic levels. It is visible that in countries with worse institutional conditions taxes have a significantly more negative impact, since the taxation can be excessive in regards to the produced public goods. If part of tax revenues gets lost in a nontransparent tax system then the public goods will not be produced at such rate as it would be adequate to the taxation level. This fact can have a direct impact on economic growth.

However, the differences in tax impacts can be caused also by different economic levels. As it was already mentioned, in $\mathrm{OECD}_{15}$ (worse institutional conditions) the unitary impact of capital accumulation is higher than in $\mathrm{OECD}_{19}$ (good institutional conditions). It is necessary to realize that income represents the main source of savings and investments. So if there exist income taxes in individual tax systems their negative impact on economic growth must be stronger in the less developed countries (due to the higher marginal productivity of capital, see above). On the other hand consumption taxes should not show significantly different results between analyzed groups of countries.

The results of our analysis confirm the above mentioned. Personal income taxes have an apparent negative impact only in the countries with worse institutional conditions. In the developed countries, this impact is statistically insignificant and therefore it is unprovable. This fact can be probably connected to the significance of savings creation as a basic source of investments and economic growth. It is necessary to realize that the importance of savings can be together with capital inflow the essential factor which determines the level of growth in less developed countries.

The impact of corporate taxation is almost the same in both categories. Therefore the importance of capital as a basic source of economic growth is in both groups of countries similar. However, within wider contexts it is necessary to realize that the difference of capital importance must be perceived especially through the above explained impact of personal income taxes.

Social security contributions are from the view of their impact on economic growth in both cases the most harmful. Their negative impact is also much more evident in countries with worse institutional conditions. This can be explained by the fact that social security contributions are financing unproductive government spending and their ratio (measured by tax quota) is usually the highest in overall tax mix.

Property taxes are statistically significant only in countries with better institutional conditions with positive impact on economic growth. This fact is connected to the increasing ratio of property taxes on the total tax mix in countries with better institutional conditions. On the other hand in countries with worse institutional conditions (e.g. the Czech Republic, Slovak Republic), the property taxes have only an insignificant function in the comparison with e.g. the labour taxation in their tax systems. 
Consumption taxes, specifically value added taxes, were in both groups of countries statistically insignificant.

\section{Conclusion}

The aim of this paper was to examine the impact of fiscal policy on economic growth depending on the institutional conditions in the OECD over the time period 2000-2012. The initial assumption that the differences in institutional conditions can influence economic growth was confirmed to a certain level.

The separation of countries according to the institutional conditions corresponds with the classification of countries according to the level of economic development. This relation is natural, since the quality of institutional environment positively influences the economic development. On the other hand economic development positively influences the quality of institutional environment, too. This must be taken into account when the results are interpreted.

The empirical results show following. Capital accumulation and human capital have a higher positive impact on economic growth in the countries with worse institutional conditions $\left(\mathrm{OECD}_{15}\right)$ than in the second group of countries $\left(\mathrm{OECD}_{19}\right.$ - countries with better institutional conditions). The conclusion is clear here. Countries in the first group are less economically developed and they have lower capital stock per resident available. Therefore (due to the decreasing marginal productivity of capital) the unitary accumulation of physical and human capital have a higher positive impact on economic growth.

The impact of government spending on economic growth is positive in $\mathrm{OECD}_{15}$ and negative in $\mathrm{OECD}_{19}$. It can be assumed that in less developed countries the investment into infrastructure prevails and their impact is pro-growth. In developed countries the existence of Wagner's law is showed. However to confirm this hypothesis strictly the future analysis must divide total government spending according to the function classification of government spending (COFOG).

On the other hand taxation impact on economic growth is more negative in the countries with lower fiscal transparency. This result can be connected with institutional conditions (chaotic and non-transparent tax system) and different economic level (more negative impact of income taxes in countries with more productive capital accumulation). For future research the using of World Tax Index as an effective approximator of taxation is necessary. Tax quota is characteristic by many shortages and therefore some results can be distorted.

\section{Acknowledgements}

This paper was financially supported by the VŠB - Technical University SGS grant project No. SP2014/145 "The Influence of Structure of Government Spending and Taxes in Selected Sectors and Economic Growth in the Czech Republic“.

\section{References}

[1] ALESINA, A. et al., 1999. Fiscal Policy, Profits and Investment. National Bureau of Economic Research Working Paper, No. 7207.

[2] BARRO, R. and X. SALA-I-MARTIN, 2004. Economic Growth. $2^{\text {nd }}$ ed. Cambridge: MIT Press. ISBN 0-262-02553-1 
[3] BRIXI, H. and T. IRWIN, 2004. Fiscal Support for Infrastructure: Toward a More Effective and Transparent Approach. ADB-JBIC, World Bank East Asia Pacific Infrastructure Flagship Study.

[4] BUTKIEWICZ, J. and H. YANIKKAYA, 2011. Institutions and the Impact of Government Spending on Growth. Journal of Applied Economics, 14(11), 319-341. ISSN 1514-0326.

[5] DJANKOV, S. et al., 2003. The New Comparative Economics. Journal of Comparative Economics, 31(4), 595-619. ISSN 0147-5967.

[6] DREßLER, D., 2012. The Impact of Corporate Taxes on Investment: An Explanatory Empirical Analysis for Interested Practitioners. Zentrum für Europäische Wirtschaftsforschung Working Paper, No. 12040.

[7] DROBISZOVÁ, A., 2013. The Impact of Productive and Unproductive Government Expenditure on Economic Growth in OECD Countries. In: Z. MACHOVÁ, ed. Conference Proceedings 3rd International Scientific Conference TAXES IN THE WORD. Ostrava: VŠB-TU, p. 37-48. ISBN 978-80-248-3133-6.

[8] DWENGER, N., 2009. Corporate Taxation and Investment: Explaining Investment Dynamics with Firm-Level Panel Data. German Institute of Economic Research Discussion Paper, No. 924.

[9] FOLSCHER, A., W. KRAFCHIK and I. SHAPIRO, 2000. Transparency and Participation in the Budget Process. IDASA, Budget Information Service and the International Budget Project.

[10] GEMMEL, N., R. KNELLER, and I. SANZ, 2011. The Timing and Persistence of Fiscal Policy Impacts on Growth: Evidence from OECD Countries. Economic Journal, 121(550), F33-F58. ISSN 1468-0297.

[11] IMF, 2007. Manual on Fiscal Transparency. International Monetary Fund - Fiscal Affairs Departure, Manual on Fiscal Transparency.

[12] JONES, L. and R. MANUELLI, 1999. On the Taxation of Human Capital. University of Minesota - Department of Economics Working Paper.

[13] KAUFMANN, D., A. KRAAY and M. MASTRUZZI, 2010. The Worldwide Governance Indicators: Methodology and Analytical Issues. World Bank Working Paper, No. 5430.

[14] KNELLER, R., M. BLEANEY and M. GEMMELL, 1999. Fiscal Policy and Growth: Evidence from OECD Countries. Journal of Public Economics, 74(2), 171-190. ISSN 0047-2727.

[15] KOPITS, G. and J. CRAIG, 1998. Transparency in Government Operations. Washington: International Monetary Fund.

[16] KOTLÁN, I. and Z. MACHOVÁ, 2012. Vliv zdanění korporací na ekonomický růst: selhání daňové kvóty? Politická ekonomie, 60(6), 743-763. ISSN 0032-3233.

[17] KOTLÁN, I., Z. MACHOVÁ and L. JANÍČKOVÁ, 2011. Vliv zdanění na dlouhodobý ekonomický růst. Politická ekonomie, 59(5), 638-658. ISSN 0032-3233.

[18] LIN, S., 2001. Taxation, Human Capital Accumulation and Economic Growth. Japanese Economic Review, 52(2), 185-197. ISSN 1468-5876. 
[19] LUCAS, R., 1988. On the Mechanics of Economic Development. Journal of Monetary Economics, 22(1), 3-42. ISSN 0304-3932.

[20] MACEK, R., 2014. The Impact of Taxation on Economic Growth: Case Study of OECD Countries. Review of Economic Perspectives, 14(4), 309-328. ISSN 1804-1663.

[21] MACHOVÁ, Z., 2013. Pro-growth Efffects of (Un)productive Government Spending in the OECD. In: Z. MACHOVÁ, ed. Conference Proceedings 3rd International Scientific Conference TAXES IN THE WORD. Ostrava: VŠB-TU, p. 103-112. ISBN 978-80-2483133-6.

[22] MANKIW, G., D. ROMER and D. WEIL, 1992. A Contribution to the Empirics of Economic Growth. The Quarterly Journal of Economics, 107(2), 407-437. ISSN 15314650.

[23] NORTH, D. and R. THOMAS, 1973. The Rise of the Western World: A New Economic History. Cambridge: Cambridge University Press. ISBN 9780521290999.

[24] OLSON, M., 1982. The Rise and Decline of Nations. Yale: Yale University Press. ISBN 0300030797.

[25] PALOMBA, G., 2004. Capital Income Taxation and Economic Growth in Open Economies. International Monetary Fund Working Paper, No. 04/91.

[26] ROMER, P., 1986. Increasing Returns and Long-Run Growth. Journal of Political Economy, 94(5), 1002-1037. ISSN 0022-3808.

[27] SOLOW, R., 1956. Contribution to the Theory of Economic Growth. The Quarterly Journal of Economics, 70(1), 65-94. ISSN 1531-4650.

[28] SWAN, T., 1956. Economic Growth and Capital Accumulation. The Economic Record, 32(2), 334-361. ISSN 1475-4932.

[29] TANZI, V. and Z. ZEE, 1997. Fiscal Policy and Long-run Growth. International Monetary Fund Working Paper, No. 44-2.

[30] TEIXEIRA, A. and N. FORTUNA, 2003. Human Capital, Innovation Capability and Economic Growth. Faculdade de Economia Working Paper, No. 131.

[31] TOSUN, M. and S. ABIZADEH, 2005. Economic Growth and Tax Components: An Analysis of Tax Changes in OECD. Applied Economics, 37(19), 1466-4283. ISSN 15140326.

[32] WOOLDRIDGE, J., 2009. Introductory Econometrics: A Modern Approach. Mason: South-Western CENGAGE Learning. ISBN 978-1111531041. 